\title{
Transient response improvement of direct current using supplementary control based on ANFIS for rectifier in HVDC
}

\author{
I Made Ginarsa, Agung Budi Muljono, I Made Ari Nrartha, Sultan \\ Department of Electrical Engineering, University of Mataram, Indonesia
}

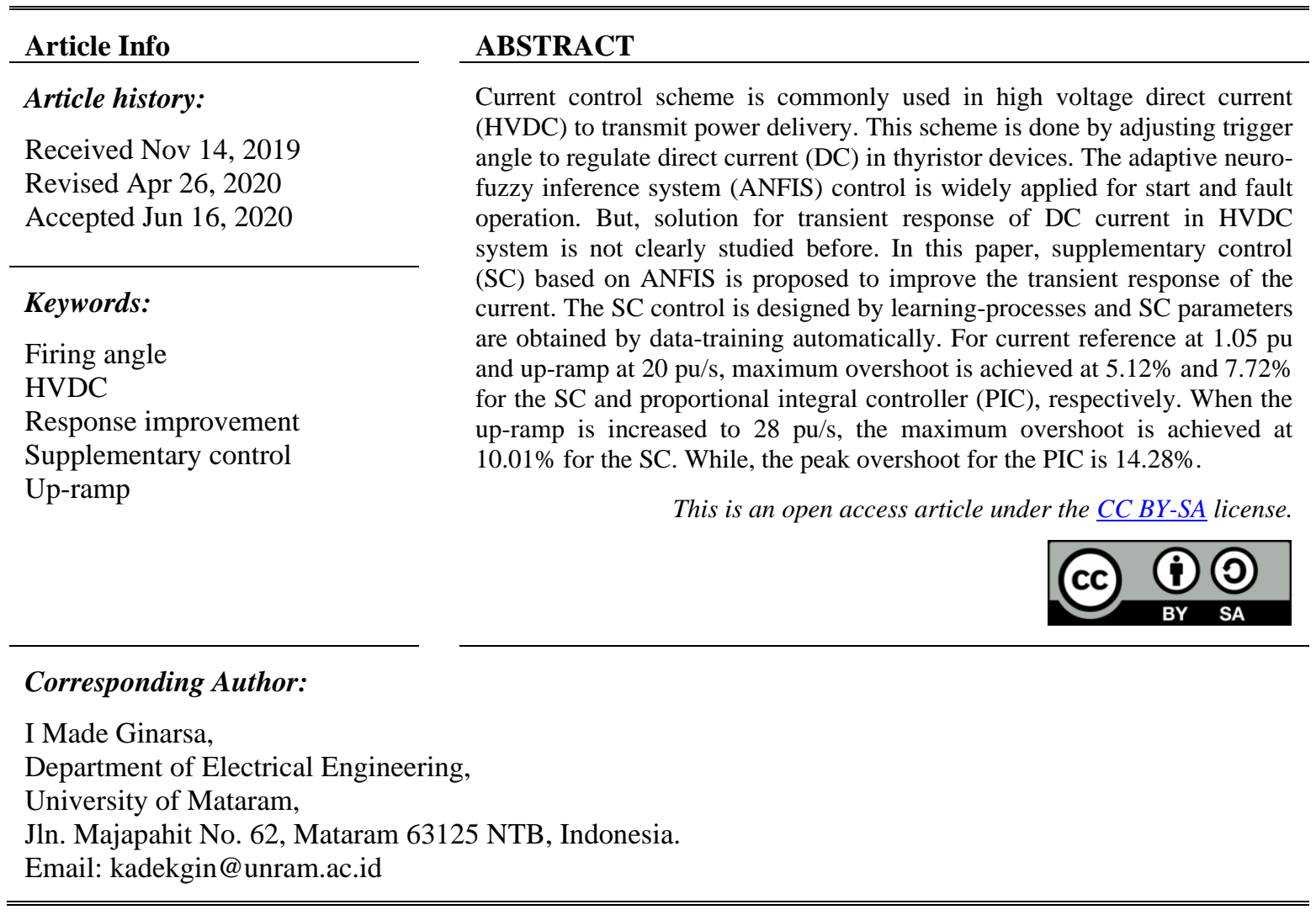

\section{INTRODUCTION}

Indonesia is an archipelago country that consists of main-islands such as: Sumatera, Java, Sulawesi, Kalimantan, Nusa Tenggara, Maluku and Papua. Most of the main-island electrical power systems are independent and separate from each other. Application of high voltage alternating current (HVAC) through long distance submarine power cable (SPC) is difficult to be built because the SPC has very high linecharging, high reactive power losses and stability problems [1]. While, high voltage direct current (HVDC) system is very promising to overcome these problems and to be implemented in Indonesia especially for long distance HVDC using SPC. Pre-analysis of Java-Sumatra HVDC transmission has been conducted to realize the HVDC application in Indonesia power system inter-connection [2, 3].

The HVDC transmission is applied to transmit bulk electric power through transmission line over a long distance using overhead conductors or SPC [4]. The HVDC technology has several advantages compared to competing HVAC technology such as: Power plant can be located far from consumer, not need reactive power compensation in long distance HVDC transmission, can be inter-connected to HVAC for difference frequencies, to transmit more capacity of power delivery $[5,6]$. Also, development and operation costs of the HVDC are cheaper than the HVAC for long-distance transmission and friendly for environment [7]. A HVDC-link connected to a HVAC will prevent fault and oscillation propagate to neighbor the HVAC. Moreover, the HVDC is able to improve stability of inter-connected HVAC by modulating power in response to small/large disturbances [8], line commutated converter (LCC)-HVDC links are applied to enhance stability of permanent magnet synchronous generator offshore wind turbine [9] and 
large-scale integration of wind, solar and marine-current generation [10] fed to multi-machine power systems (PS).

To help the HVDC in operation and control managements, a comprehensive small-signal model of a LCC-voltage source converter (VSC) HVDC-link and their eigen-analysis of the model are built and impact of parameter to system damping is studied. The DC-current control parameters of LCC, DC-voltage control parameters of VSC DC-side capacitor of VSC and smoothing reactor of LCC have large effect to the damping oscillatory mode of power systems. Also, larger PI gain of the VSC, and smaller PI gain of the LCC are able to improve damping of the dominant mode [11]. A model for hybrid multi-in-feed HVDC (H-MIDC) link and its controller are developed to simulate small-signal model. The H-MIDC link is located close in a common receiving $\mathrm{AC}$ grid. The dynamic performances of $\mathrm{H}-\mathrm{MIDC}$ are improved using optimized parameters control [12]. Analysis of HVDC-line with off-shore resources and storage devices is done using optimal power flow strategy [13]. Some differential equation sets are designed to develop HVDC in averagevalue model to simplify the HVDC model without including switching-device mechanism and neglected high frequency [14], and this model is applied to power system analysis [15]. Dynamic properties in both AC/DC of HVDC-link are presented on frequency-domain model. This model is used to control and stability analysis of overall power systems, that Part I describes fixed-commutation overlap method [16] and Part II explains the model upgraded by varying-overlap angle [17].

However, HVDC control has non-linear characteristics include several properties in converter/inverter devices, transformer saturation and presence of filters in AC/DC-side and harmonic generation. The non-linear characteristics make the regulation of HVDC are complicated and challenged in PS and power electronic fields. Predictive control is proposed to improve PS stability [18]. Control parameter is optimized to improve the HVDC performance using electromagnetic transient analysis program [19]. The HVDC control is simplified by building a novel space-vector pulse width modulation (SVPWM) [20] and simplification of SVPWM 3-dimension control is applied to regulate 3-phase 4-leg of inverters [21].

Artificial intelligent application is very attractive research and it is implemented in some fields such as: Genetic algorithm to optimize robustness and efficiency of micro-grid DC solar-system structures [22], firefly algorithm to optimize PID parameter of automatic generation control in multi-area [23]. Grey wolf optimizer (GWO) is used to optimize power flow wind farm integrated to PS [24], to optimize power allocation to realize plug-and-play capability of micro-grid system [25], to minimize operating cost and active power loss by optimizing reactive power generation [26] and to estimate input-output parameters of thermal plant [27]. The GWO is also applied on power system stabilizer to damp local oscillation in multimachine [28] and inter-area oscillation in wide-area [29]. While, development of neural control is done in [30] to improve stability of power transmission and in [31] to help dispatcher in decision making on mapping of PS fault instantaneously. Fuzzy control is developed to design of wind-PV combined-generator model [32], to regulate induction motor speed combined by proportional-integral control [33], and fuzzy type-2 to control permanent magnet synchronous machine through digital-signal processing [34]. The neural network-fuzzy model is applied to advance direct power control for grid-connected to distributed generator [35]. An adaptive neuro-fuzzy inference system (ANFIS) has been designed to regulate converter [36] and inverter [37] of HVDC-line, and to control voltage collapse in PS [38]. Also, the ANFIS scheme is used to control, detect fault, and protect [39, 40] of HVDC, and to protect HVDC-light from AC fault [41]. Moreover, combination of ANFIS and fuzzy type-2 has been used to maintain large-scale PS stability [42].

Transient responses of voltage/current are very important in PS and power electronic researches because these responses should be constrained to protect the systems and devices from over-voltage/current on its operation. To improve transient response, some control schemes are proposed such as: ANFIS algorithm based on additional PID-loop to improve transient voltage response in PS [43], feed-forward compensation method [44], feed-forward capacitor [45], triangular wave generator through to adjust its slope [46] for DC-DC converters and feed-forward compensation model for DC-AC converter based on space vector-pulse width modulation [47]. However, research topic of transient responses improvement in HVDC using ANFIS control scheme has not been clearly discussed. This remaining paper is organized as follows: Design of supplementary control based on ANFIS model is described in Section 2. Results and discussion are explained in Section 3. And, finally conclusion is summarized in Section 4.

\section{DESIGN OF SUPPLEMENTARY CONTROL BASED ON ANFIS MODEL}

Supplementary control (SC) is proposed in thyristor-based rectifier of HVDC system to help the PI regulator to reduce transient direct current response, especially when the up-ramp value was higher (such as: $20 \mathrm{pu} / \mathrm{s}$ or more). Where, the SC is defined by PI control plus ANFIS-based control. The HVDC and its control blocks are taken from [48] and controller of the system is shown in Figure 1(a). While, current 
reference pattern of HVDC at start-up is illustrated in Figure 1(b). The ANFIS-based controller is built by ANFIS model [49]. Block diagram of SC is depicted in Figure 2.

The ANFIS controller of SC is developed by training process. Inputs data of training process are current error $\left(I_{e r r}\right)$, its derivative $\left(d I_{\text {err }}\right)$ and additional trigger angle from the supplementary control (AlphasC, $\left.\alpha_{S C}\right)$. Where, the current error was obtained by difference of direct current $\left(I_{d}\right)$ and reference current $\left(I_{r e f}\right)$. In the training process, the $\left(I_{e r r} ; d I_{e r r}\right)$ and $\left(A l p h a_{S C}, \alpha_{S C}\right)$ were formed into 5,000 input-output matrix data. The training process was done in off-line session. Result of the training process was a SC controller based on ANFIS model as shown in Figure 3. The ANFIS structure and pattern of input-output control are shown in Figures 4(a) and (b), respectively. Furthermore, the ANFIS model is embedded to fuzzy controller in Simulink [50] model as described in Figure 3. Next, the SC performance is evaluated in Section 3.

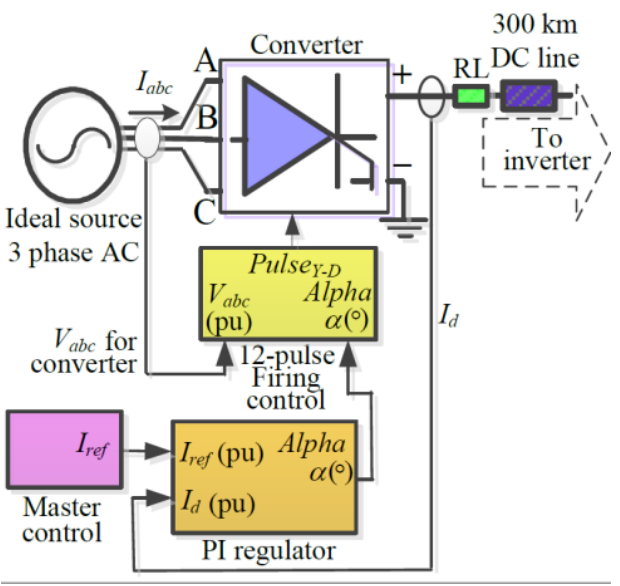

(a)

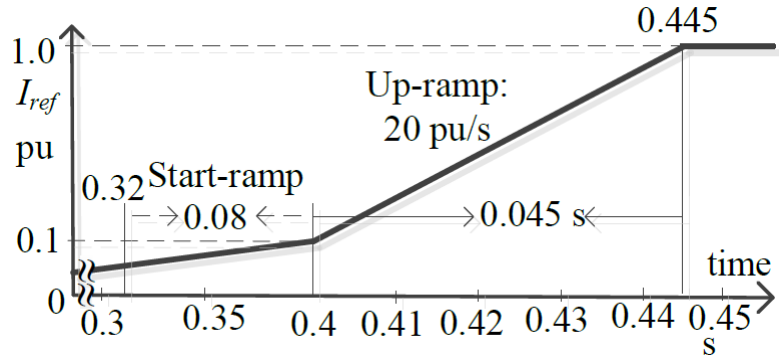

(b)

Figure 1. Control scheme for HVDC transmission system,

(a) diagram block of thyristor-based rectifier, (b) current reference $\left(I_{r e f}\right)$ pattern at up-ramp $20 \mathrm{pu} / \mathrm{s}$

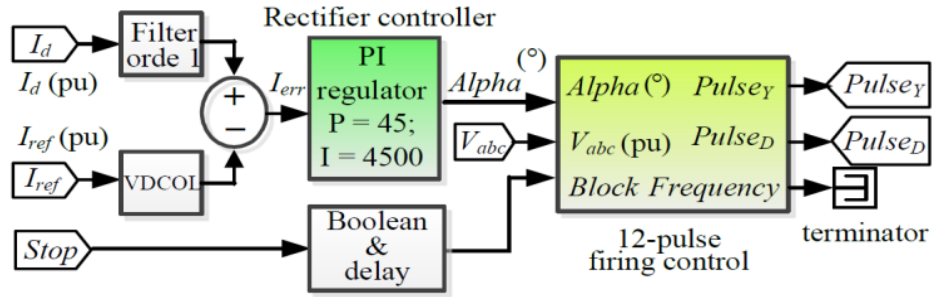

Figure 2. Trigger angle (Alpha) controller using PI regulator

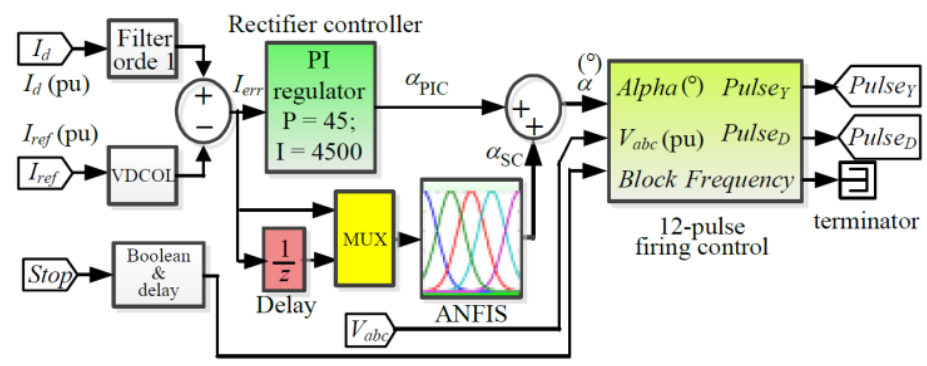

Figure 3. Supplementary controller (SC) to improve transient current response 


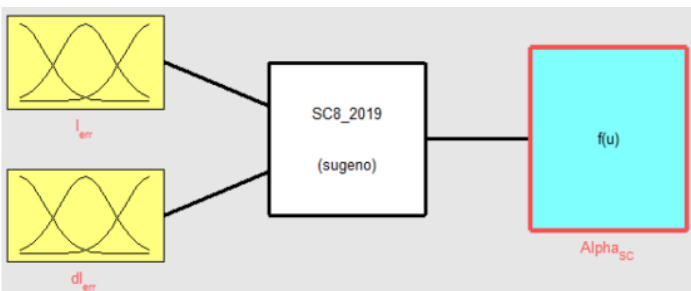

(a)

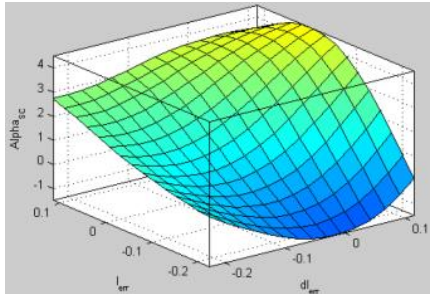

(b)

Figure 4. Supplementary control (SC) based on ANFIS Sugeno model,

(a) ANFIS structure for SC, (b) pattern of input-output control

\section{RESULTS AND DISCUSSION}

In this research, simulation was done by using Matlab/Simulink [50] on a PC computer. Which is specified as follows: Proc. Intel-i5-7400, cache capacity 6,0 MB, Freq. 3.0 GHz, LGA 1151 windows 7 operating system. The SC was tested to regulate firing angle on rectifier-side of HVDC system.

\subsection{Improvement of transient response when final value of current reference set at 0.95 pu}

In this case, PI controller parameters were set at the default values $\mathrm{P}=4500$; and $\mathrm{I}=45$ [48]. The master controller parameters were set as follows. Up-ramp rate was increased at the values of 20, 22, 24, 26 and $28 \mathrm{pu} / \mathrm{s}$. Moreover, the up-ramp time and up-ramp final value were taken at the time of $0.3 \mathrm{~s}$ and the value of $0.95 \mathrm{pu}$, respectively. The simulation results are described in Figures 5, 6 and listed in Table 1.

Figure 5 and Table 1 show the transient responses of direct current for respective controllers when the up-ramp rate of current reference was set at $20 \mathrm{pu} / \mathrm{s}$. There are depicted that response parameters for PI controller (PIC) were as follows: $9.85 \%, 3.843 \%, 0.459 \mathrm{~s}, 0.548 \mathrm{~s}$ and $5.953 \times 10-2 \%$ for maximum overshoot (Mp), start-time error (estr), peak time (tp), settling time (ts) and steady-state error (ess), respectively. Meanwhile, the response parameters that given by SC were as follows: $5.63 \%, 3.797 \%, 0.458 \mathrm{~s}, 0.545 \mathrm{~s}$ and $3.233 \times 10-2 \%$ for maximum overshoot, start-time error, peak time, settling time and steady-state error, respectively. Figure 6 and Table 1 illustrate the transient responses when the up-ramp rate of current reference was increased to $28 \mathrm{pu} / \mathrm{s}$. Responses of the PI controller were as follows: $15.18 \%, 2.708 \%, 0.452 \mathrm{~s}$, $0.568 \mathrm{~s}$ and $5.651 \times 10-2 \%$ for maximum overshoot, start-time error, peak time, settling time and steady-state error. While, the responses that given by the SC were: $9.77 \%, 2.856 \%, 0.451 \mathrm{~s}, 0.550 \mathrm{~s}$ and $2.564 \times 10-2 \%$ for maximum overshoot, start-time error, peak time, settling time and steady-state error, respectively. The SC is able to improve the transient response of direct current based on the response parameters are given in this scenario.

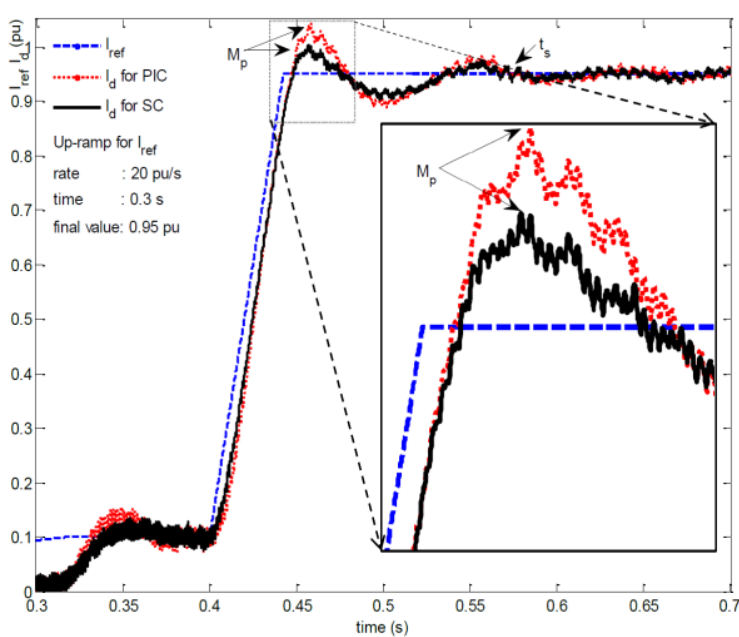

Figure 5. Transient response improvement for direct current at current reference $0.95 \mathrm{pu}$.

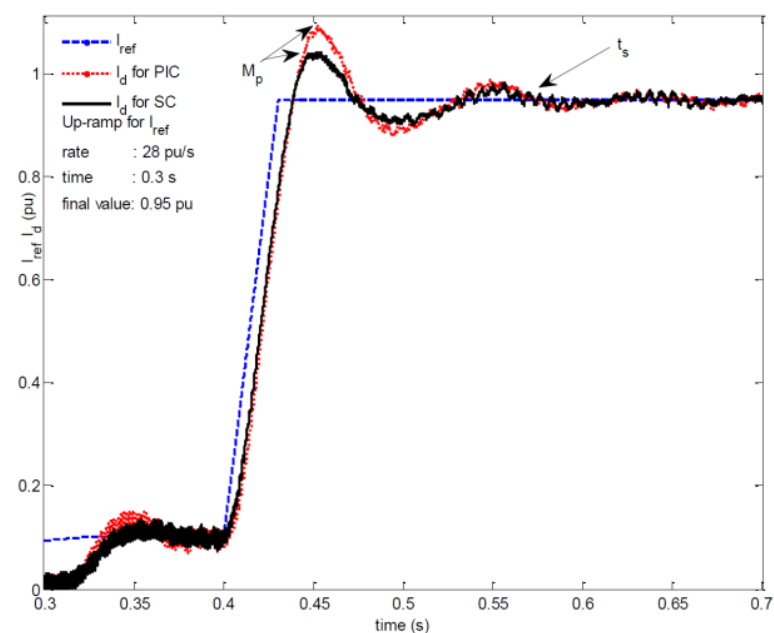

Figure 6. Transient response for current reference 0.95 and up-ramp $28.0 \mathrm{pu} / \mathrm{s}$. 
Table 1. The performance of SC when final value of current reference at $0.95 \mathrm{pu}$.

\begin{tabular}{|c|c|c|c|c|c|c|c|c|c|c|}
\hline \multirow[b]{2}{*}{$\begin{array}{c}\text { up-ramp } \\
(\mathrm{pu} / \mathrm{s})\end{array}$} & \multicolumn{5}{|c|}{ PI control (PIC) } & \multicolumn{5}{|c|}{ Supplementary control (SC) } \\
\hline & $\begin{array}{l}M_{p} \\
(\%)\end{array}$ & $\begin{array}{l}e_{s t r} \\
(\%)\end{array}$ & $\begin{array}{l}t_{p} \\
(\mathrm{t})\end{array}$ & $\begin{array}{l}t_{s} \\
(\mathrm{t})\end{array}$ & $\begin{array}{c}e_{s s} \\
\times 10^{-2}(\%)\end{array}$ & $\begin{array}{l}M_{p} \\
(\%)\end{array}$ & $\begin{array}{l}e_{s t r} \\
(\%)\end{array}$ & $\begin{array}{l}t_{p} \\
(\mathrm{t})\end{array}$ & $\begin{array}{c}t_{s} \\
(\mathrm{t})\end{array}$ & $\begin{array}{c}e_{s s} \\
\times 10^{-2}(\%)\end{array}$ \\
\hline 20 & 9.85 & 3.843 & 0.459 & 0.548 & 5.953 & 5.63 & 3.797 & 0.458 & 0.545 & 3.233 \\
\hline 22 & 11.84 & 3.446 & 0.461 & 0.557 & 0.669 & 6.91 & 3.666 & 0.454 & 0.546 & 2.295 \\
\hline 24 & 13.27 & 3.156 & 0.460 & 0.561 & 2.054 & 7.92 & 3.415 & 0.453 & 0.547 & 4.574 \\
\hline 26 & 14.29 & 3.157 & 0.454 & 0.565 & 4.209 & 9.86 & 3.201 & 0.453 & 0.548 & 4.011 \\
\hline 28 & 15.18 & 2.708 & 0.452 & 0.568 & 5.651 & 9.77 & 2.856 & 0.451 & 0.550 & 2.564 \\
\hline
\end{tabular}

\subsection{Performance of SC when the final value of current reference set at $1.0 \mathrm{pu}$}

Furthermore, the final value of current reference was increased to $1.0 \mathrm{pu}$. The up-ramp rates and upramp time were set as same as the values and time before. The results are depicted in Figures 7, 8 and in Table 2. From Figure 7 and Table 2 we can see that the maximum overshoot was achieved at the value of 8.96 and $5.73 \%$ for the PIC and SC when the up-ramp rate at $20 \mathrm{pu} / \mathrm{s}$, respectively. The start-time error was at the values of 3.638 and $4.025 \%$. Peak time was at time $0.464 \mathrm{~s}$ for the both controllers. The settling time was achieved at time 0.568 and $0.550 \mathrm{~s}$. The steady-state error was achieved at the values of (3.042 and $0.368) \times 10^{-2} \%$ for the PIC and SC, respectively. Figure 7 shows that maximum overshoot of the PI controller is higher than the supplementary controller.

The Figure 8 and Table 2 shows maximum overshoot was achieved at the value of 14.22 and $9.75 \%$ for the PI controller and supplementary controller when the up-ramp rate at $28 \mathrm{pu} / \mathrm{s}$, respectively. The starttime error was at the values of 2.451 and $2.627 \%$. Peak time was at time 0.452 and $0.451 \mathrm{~s}$. The settling time was achieved at time 0.579 and 0.569 s. And, the steady-state error was at the values of $(0.202$ and $0.374) \times 10^{-2} \%$ for the PI controller and supplementary controller, respectively.

It is found that the maximum overshoot of direct current equipped by supplementary controller is lower than PI controller. Also, settling time of the supplementary controller is shorter than the other. It is found that the supplementary controller is more effective to reduce peak overshoot of direct current than the PI controller in this scenario.

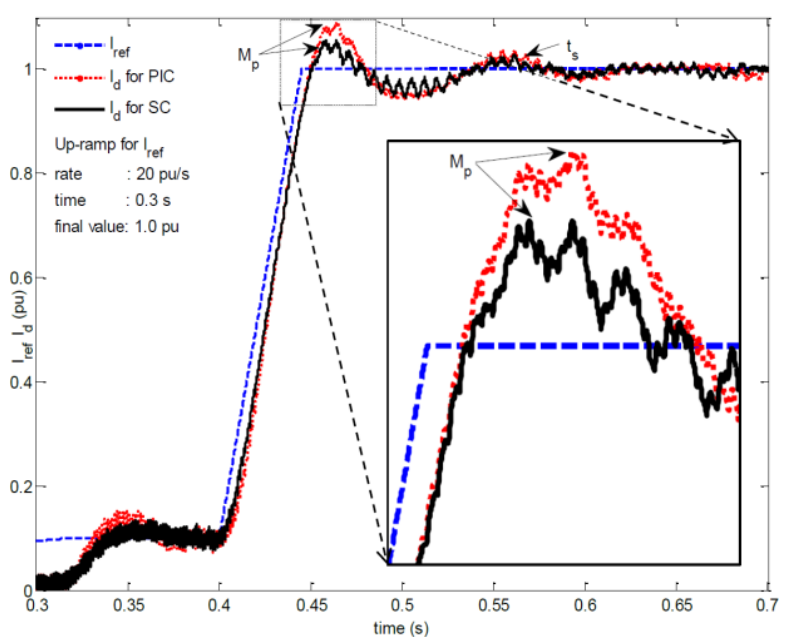

Figure 7. Transient response for current reference 1.0

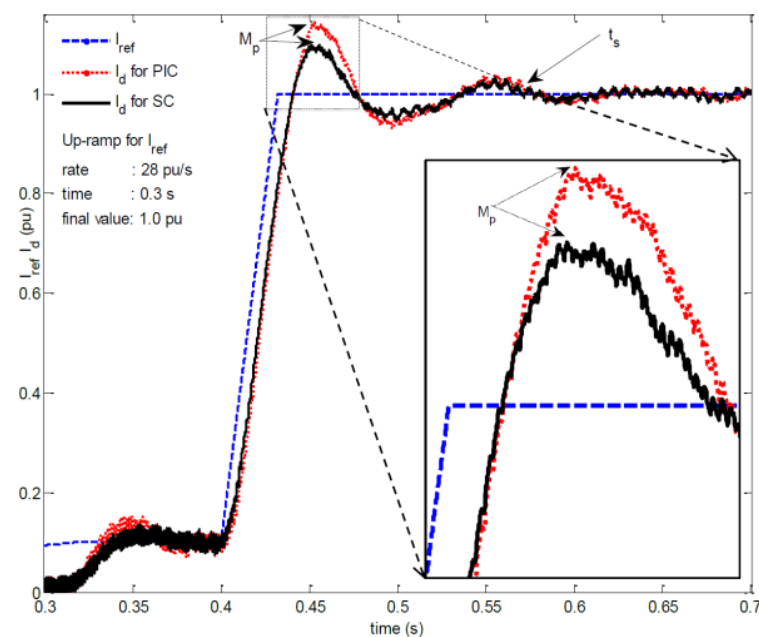

Figure 8. Transient response for current reference 1.0 and up-ramp $28.0 \mathrm{pu} / \mathrm{s}$

Table 2. The performance of supplementary control at current reference $=1.0 \mathrm{pu}$.

\begin{tabular}{|c|c|c|c|c|c|c|c|c|c|c|}
\hline \multirow[b]{2}{*}{$\begin{array}{c}\text { up-ramp } \\
(\mathrm{pu} / \mathrm{s})\end{array}$} & \multicolumn{5}{|c|}{ PI control (PIC) } & \multicolumn{5}{|c|}{ Supplementary control (SC) } \\
\hline & $\begin{array}{l}M_{p} \\
(\%)\end{array}$ & $\begin{array}{l}e_{s t r} \\
(\%)\end{array}$ & $\begin{array}{l}t_{p} \\
(\mathrm{t})\end{array}$ & $\begin{array}{l}t_{s} \\
(\mathrm{t})\end{array}$ & $\begin{array}{c}e_{s s} \\
\times 10^{-2}(\%)\end{array}$ & $\begin{array}{l}M_{p} \\
(\%)\end{array}$ & $\begin{array}{l}e_{s t r} \\
(\%)\end{array}$ & $\begin{array}{l}t_{p} \\
(\mathrm{t})\end{array}$ & $\begin{array}{l}t_{s} \\
(\mathrm{t})\end{array}$ & $\begin{array}{c}e_{s s} \\
\times 10^{-2}(\%)\end{array}$ \\
\hline 20 & 8.96 & 3.638 & 0.464 & 0.568 & 3.042 & 5.73 & 4.025 & 0.464 & 0.550 & 0.368 \\
\hline 22 & 10.65 & 3.326 & 0.461 & 0.571 & 1.264 & 7.36 & 3.686 & 0.459 & 0.553 & 1.901 \\
\hline 24 & 12.03 & 3.036 & 0.460 & 0.573 & 2.154 & 7.73 & 3.321 & 0.453 & 0.559 & 0.906 \\
\hline 26 & 13.25 & 3.036 & 0.454 & 0.575 & 0.380 & 9.02 & 2.972 & 0.453 & 0.564 & 0.072 \\
\hline 28 & 14.22 & 2.451 & 0.452 & 0.579 & 0.202 & 9.75 & 2.627 & 0.451 & 0.569 & 0.374 \\
\hline
\end{tabular}




\subsection{Improvement of direct current transient response at 1.05 pu}

Moreover, the system is tested by increasing the final value of direct current again to $1.05 \mathrm{pu}$. The results are described in Figures 9, 10 and Table 3. Table 3 depicts maximum overshoots of direct current were achieved at the values of 7.72-14.28\% for the PIC when the up-ramp rates were taken at 20-28 pu/s, respectively. Errors at start-time are achieved at the values of 3.63-2.46\%. The settling time for the PIC were at times of $0.571-0.578 \mathrm{~s}$. The steady-state errors were achieved at the values of $(3.042-0.202) \times 10^{-2} \%$. Figure 9 shows transient responses of DC current for PI and SC for up-ramp rates at $20 \mathrm{pu} / \mathrm{s}$.

While, the maximum overshoots of direct current were achieved at the values of $5.73-9.75 \%$ for the $\mathrm{SC}$ when the up-ramp rates were at $20-28 \mathrm{pu} / \mathrm{s}$. Errors at start-time were at the values of $4.025-2.627 \%$. The settling times were at times of $0.550-0.569 \mathrm{~s}$. The steady-state errors were achieved at the values of $(0.368-$ $0.374) \times 10^{-2} \%$. Also, transient response of DC current is depicted in Figure 10 for the PIC and SC controller, respectively, when the up-ramp rate is given at $28 \mathrm{pu} / \mathrm{s}$.

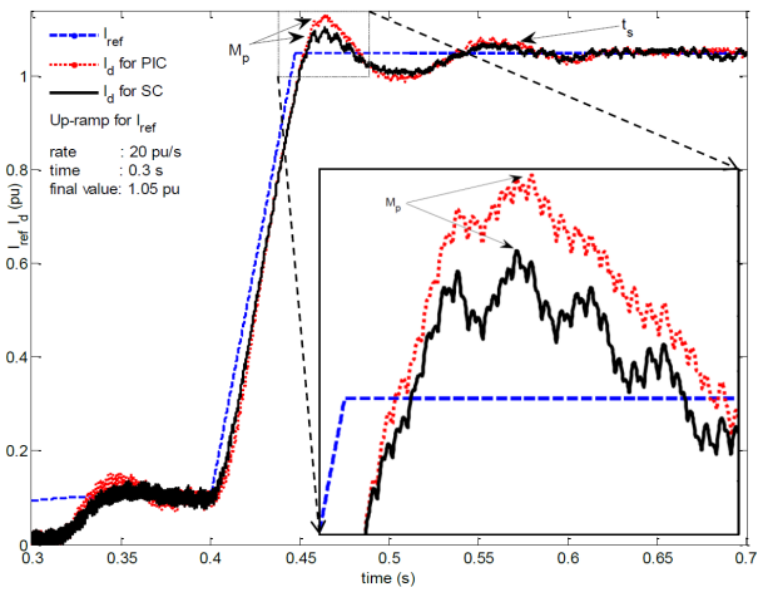

Figure 9. Transient response improvement for current reference $1.05 \mathrm{pu}$.

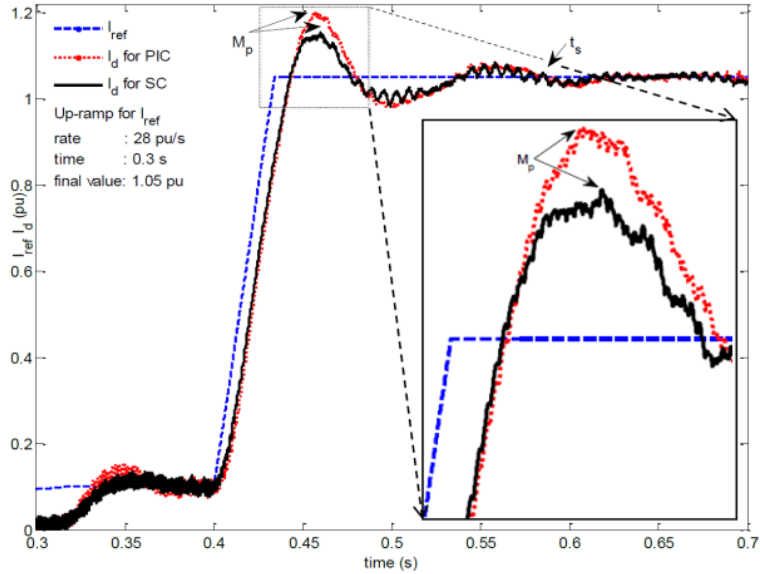

Figure 10. Transient response improvement for current reference $1.05 \mathrm{pu}$ and up-ramp $28.0 \mathrm{pu} / \mathrm{s}$.

Based on the results, peak overshoot and settling time of SC are lower and shorter than the peak overshoot and settling of the PIC. On the other hand, the error at start-time and steady state error for all controllers are small $(<5 \%)$ and very small $\left(<10^{-2} \%\right)$, respectively. The SC is more effective to reduce the transient response of direct current than the PIC for the up-ramp of reference current at 20-28 pu/s.

Table 3. The performance of supplementary control when reference current was set at $1.05 \mathrm{pu}$.

\begin{tabular}{|c|c|c|c|c|c|c|c|c|c|c|}
\hline \multirow[b]{2}{*}{$\begin{array}{l}\text { up-ramp } \\
(\mathrm{pu} / \mathrm{s})\end{array}$} & \multicolumn{5}{|c|}{ PI control (PIC) } & \multicolumn{5}{|c|}{ Supplementary control (SC) } \\
\hline & $\begin{array}{l}M_{p} \\
(\%)\end{array}$ & $\begin{array}{l}e_{s t r} \\
(\%)\end{array}$ & $\begin{array}{l}t_{p} \\
(\mathrm{t})\end{array}$ & $\begin{array}{l}t_{s} \\
(\mathrm{t})\end{array}$ & $\begin{array}{c}e_{s s} \\
\times 10^{-2}(\%)\end{array}$ & $\begin{array}{l}M_{p} \\
(\%)\end{array}$ & $\begin{array}{l}e_{s t r} \\
(\%)\end{array}$ & $\begin{array}{l}t_{p} \\
(\mathrm{t})\end{array}$ & $\begin{array}{l}t_{s} \\
(\mathrm{t})\end{array}$ & $\begin{array}{c}e_{s s} \\
\times 10^{-2}(\%)\end{array}$ \\
\hline 20 & 7.72 & 3.215 & 0.466 & 0.571 & 2.863 & 5.12 & 4.343 & 0.463 & 0.548 & 4.844 \\
\hline 22 & 10.12 & 3.611 & 0.463 & 0.573 & 4.906 & 5.99 & 4.302 & 0.460 & 0.552 & 3.787 \\
\hline 24 & 12.34 & 3.293 & 0.461 & 0.575 & 6.537 & 6.64 & 3.518 & 0.460 & 0.563 & 0.967 \\
\hline 26 & 13.38 & 3.293 & 0.460 & 0.579 & 6.319 & 8.22 & 3.220 & 0.455 & 0.568 & 1.936 \\
\hline 28 & 14.28 & 2.793 & 0.457 & 0.580 & 7.028 & 10.01 & 2.992 & 0.460 & 0.570 & 2.735 \\
\hline
\end{tabular}

\section{CONCLUSION}

Application of SC for HVDC based on ANFIS model is done in this research. The design process of ANFIS model is also explained before the control applied to the HVDC system. Simulation results of HVDC with SC are compared to the results from proportional integral control (PIC) to verify the validity of the proposed controller. The results show that maximum overshoots are achieved at $5.63 \%$ and $9.85 \%$ for SC and PIC, when current reference and up-ramp are set at $0.95 \mathrm{pu}$ and $20 \mathrm{pu} / \mathrm{s}$. Moreover, the current reference and up-ramp are increased to $1.05 \mathrm{pu}$ and $28 \mathrm{pu} / \mathrm{s}$. The maximum overshoots for SC and PIC are achieved at $10.01 \%$ and $14.01 \%$ and $14.28 \%$, respectively. The proposed control is able to improve the transient response by reducing the maximum overshoot for all simulations. 


\section{ACKNOWLEDGEMENTS}

We appreciate to the Directorate General of Higher Education (DGHE) Republic of Indonesia to support of this research through decentralization Penelitian Dasar Unggulan Perguruan Tinggi (PDUPT) scheme 2018-2019 University of Mataram.

\section{REFERENCES}

[1] A. Korompili, Q. Wu and H. Zhao, "Review of VSC HVDC connection for offshore wind power integration," IJEPES, vol. 59, 2016.

[2] R. Faizal, et al., "Sumatra-Java transmission system modelling and system impact analysis," Proc. of Conf. on PowerTech IEEE, Einhoven. pp. 1-6, 2015.

[3] D. Sudarmaji, G.C. Paap and L.v.d. Sluis, "Review of steady state analysis of HVDC interconnection of JavaSumatera," Proc. of Conf. on Elect. Eng. and Informatic, Bandung Indonesia, 2007.

[4] V.K. Sood, "HVDC and FACTS Controllers: Applications of Static Controllers in Power Systems," Kluwer Academic Pub, New York USA, 2004

[5] J. Arillaga, Y.H. Liu and N.R. Watson, "Flexible power transmission: The DC options," J. Wiley \& Sons, 1990.

[6] V.F. Pires, J.Fialho and J.F.Silva, "HVDC transmission system using multilevel power converters based on dual three-phase two-level inverters," IJEPES, vol. 65, pp. 191-200, 2015.

[7] R. Rudervall, J.P. Charpentier and R. Sharma, "High voltage direct current (HVDC) transmission systems technology review paper," Energy Week 2000, Washington DC, USA, 7-8 March 2014.

[8] C.R. Bayliss, B.J. Hardy, Transmission and Distribution Electrical Engineering, 4th ed., Newnes Elsevier, 2012.

[9] L. Wang and M.S.-N. Thi, "Stability enhancement of a PMSG-based offshore wind farm fed to a multi-machine system through an LCC-HVDC link," IEEE Trans. on Pow. Syst., vol. 98, 2013.

[10] L. Wang and M.S.-N. Thi, "Stability enhancement of large-scale integration of wind, solar, and marine-current power generation fed to an SG-based power system through an LCC-HVDC link," IEEE Trans. on Sustain. Energy, vol. 5, no.1, pp. 160-170, 2014.

[11] C. Guo, Z. Yin, C. Zhao and R. Iravani, "Small signal dynamics of hybrid LCC-VSC HVDC system,” IJEPES, vol. 98, pp. 362-372, 2018.

[12] C. Guo, W. Liu, C. Zhao, X. Ni, "Small signal dynamics and control parameter optimization of hybrid multi-infeed HVDC system," IJEPES, vol. 98, pp. 409-418, 2018.

[13] M.J. Carrizosa, et al., "Optimal power flow in multi-terminal HVDC grid with offshore wind farm and storage devices," IJEPES, vol. 65, pp. 291-298, 2015.

[14] H. Atigechi, et al., "Dynamic average-value model of CIGRE HVDC Benchmark system," IEEE trans. on Power Del., vol. 29, no. 5, pp. 2046-2054, 2014.

[15] S. Chinforoosh, et al., "Definitions and applications of dynamic average-value models for analysis of power systems," IEEE trans. on Power Del., vol. 25, no. 4, pp. 2655-2669, 2010.

[16] P.F. de Toledo, L. Angquist and A.-P. Nee, "Frequency domain model of an HVDC link with a line-commutated current-source converter. Part I: Fixed overlap,” IET Gene. Transm. \& Distrib., vol. 3, pp. 757-771, 2009.

[17] P.F. de Toledo, L. Angquist and A.-P. Nee, "Frequency domain model of an HVDC link with a line-commutated current-source converter. Part II: Varying overlap," IET Gene. Transm. \& Distrib., vol. 3, pp. 771-782, 2009.

[18] M. Darabian, A. Jalilvand and A. Azari, "Power system stability enhancement in the presence of renewable energy and HVDC line based on predictive control strategy," IJEPES, vol. 80, pp. 363-373, 2016.

[19] X. Zhang, et al., "Optimizing HVDC control parameters in multi-infeed HVDC system based on electromagnetic transient analysis," IJEPES, vol. 49, pp. 449-454, 2013.

[20] Z. Yinhai, et al., "A novel SVPWM modulation scheme," Applied Power Electronics Conference and Exposition (APEC) 2009, Twenty-Fourth Annual IEEE, pp. 128-131, 2009.

[21] X.S. Li, et al., "Analysis and simplification of three-dimensional space vector PWM for three-phase four-leg inverters," IEEE Trans. on Industrial Electronics, vol. 58, pp. 450-464, Feb 2011.

[22] M. D'Antonio, C. Shi, B. Wu and A. Khaligh, "Design and optimization of a solar power conversion system for space applications," IEEE Trans. on Industry Appl., vol. 55, no. 3, pp. 2310-2319, 2019.

[23] K. Jagatheesan, B. Anand, S. Samanta, N. Dey, A.S. Ashour and V.E. Balas, "Design of a proportional-integralderivative controller for an automatic generation control of multi-area power thermal systems using firefly algorithm," IEEE/CAA J. of Auto. Sinica, vol. 6, no. 2, pp. 503-515, 2019.

[24] M. Siavash, C. Pfeifer, A. Rahiminejad, B. Vahidi, "An application of grey wolf optimizer for optimal power flow of wind integrated power systems," Int. Conf. on EPE, Cezh Republic, 2017.

[25] J. Zhang, X. Wang, L. Ma, "An optimal power allocation scheme of microgrid using grey wolf optimizer," IEEE Access, vol. 7, pp. 137608-137619, 2019.

[26] S. Raj, B. Bhattacharyya, "Reactive power planning by opposition- grey wolf optimization method," Int Trans. Electr. Energ. Syst., Wiley, 2018.

[27] O. Zebua, I.M. Ginarsa, I.M.A. Nrartha, "GWO-based estimation of input-output parameters of thermal power plants," TELKOMNIKA (Telecommunication Computing Electronics and Control), vol. 18, no. 4, pp. 2235-2244, 2020.

[28] P. Dhanaselvi, S.S. Reddy, R. Kiranmayi, "Optimal tuning of multi-machine power system stabilizer parameter using grey wolf optimization (GWO) algorithm," Book Chap. Lect. Note in Elect. Eng., Springer Singapore, vol. 569,2020 . 
[29] M.R. Shakarami, L.F. Davoukhani, "Wide-area power system stabilizer design based on grey wolf optimization algorithm considering the time delay," EPSR Journal, vol. 133, pp. 149-159, 2016.

[30] B. Abdelkrim, Y. Merzong, "Robust stability power in transmission line with the use of UPFC system and neural controllers based adaptive control," International Journal of Power Electronics and Drive System (IJPEDS), vol. 10, no. 3, pp. 1281-1296, 2019.

[31] M.R. Khaldi, "Power systems voltage stability using artificial neural network," JICPST/IEEE Power India Conf., New Delhi India, 12-15 Oct. 2008.

[32] D.M. Atia, et al., "Modeling and control PV-wind hybrid system based on fuzzy logic control technique," TELKOMNIKA (Telecommunication Computing Electronics and Control), vol. 10, no. 3, pp. 431-441, 2012.

[33] R. Arulmozhiyal and K. Baskaran, "Implementation of a fuzzy PI controller for speed control of induction motors using FPGA,” Journal of Power Electronics, vol. 10, pp. 65-71, 2010.

[34] S. Wahsh, Y. Ahmed and E.A. Elzahab, "Implementation of type-2 fuzzy logic controller in PMSM drives using DSP," International Journal of Power Electronics and Drive System (IJPEDS), vol. 9, no. 3, pp. 1098-1105, 2018.

[35] M. Jamma, et al., "Advanced direct power control for grid-connected distribution generation system based on fuzzy logic and artificial neural networks techniques," International Journal of Power Electronics and Drive System (IJPEDS), vol. 8, no. 3, pp. 979-989 2017.

[36] I.M. Ginarsa, A.B. Muljono, I.M.A. Nrartha, "Simulation of ANFIS controller to line commutation based on current source converter high voltage direct current system," Proc. of CENCON IEEE, Yogya Indonesia, 16-17 Oct., 2019.

[37] I.M. Ginarsa, et al., "ANFIS-based controller to regulate firing angle of inverter in average value model-high voltage direct current transmission system," Proc. of ICSGTEIS IEEE, Bali Indonesia, pp. 1-6, 2018.

[38] I.M. Ginarsa, A. Soeprijanto and M.H. Purnomo, "Controlling chaos and voltage collapse using an ANFIS-based composite controller-static var compensator (CC-SVC) in power systems", IJEPES, vol. 46, 2013.

[39] N. Bawane, A.G. Kothari and D.P. Kothari, "ANFIS based control and fault detection of HVDC converter," HAIT Journal of Science and Engineering B, vol. 2, pp. 673-689, 2006.

[40] M.Z. Hossain, et al., "Performance analysis of a high voltage DC (HVDC) transmission system under steady state and faulted conditions," Telkomnika, vol. 8, no. 12, 2014.

[41] M.A. Kumar, N.V. Srikanth, "An adaptive neuro-fuzzy inference system controlled space vector pulse width modulation based HVDC light transmission system under AC fault conditions, Cent. Eur. J.E., vol. 4, no. 1, 2014.

[42] A.B. Muljono, et al., "Coordination of adaptive neuro-fuzzy inference system (ANFIS) and type-2 fuzzy logic power system stabilizer (T2FLS) to improve a large-scale power system stability," International Journal of Electrical and Computer Engineering (IJECE), vol. 8, no. 1, pp76-86, 2018.

[43] I.M. Ginarsa, et al., "Improvement of transient voltage response using an additional PID-loop on ANFIS-based composite controller-SVC (CC-SVC) to control chaos and voltage collapse in power systems," IEEJ trans. on Power and Energy, vol. 131, no.10, pp. 836-848, 2011.

[44] K. Sato, T. Sato and M. Sonehara, "Transient response improvement of digitally controlled DC-DC converter with feedforward compensation,” Proc. of INTELEC, Broadbeach Queenland, Australia pp. 609-614, 2017.

[45] B. Butterfield, "Optimizing transient response of internally compensated DC-DC converter with feedforward capacitor," Application report, Texas Inst., 2017.

[46] S. Wu, et al., "Transient response improvement of DC-DC buck converter by a slope adjustable triangular wave generator", IEICE Trans. on Comm., vol. E98, no.10, pp. 288-295, 2015.

[47] S.-J. Hong, et al., "Improvement of transient state response through feedforward compensation method of AC/DC power conversion system based on space vector pulse width modulation (SVPWM), "Energies J., vol. 11, 2018.

[48] S. Casario, "Thyristor-based HVDC transmission system: In Matlab demo," Hydro Quebec, Canada, 2013.

[49] J.-S.R. Jang, C.T. Sun and E. Mizuni, "Neuro-fuzzy and Soft Computing: A Computational Approach to Learning and Machine Intelligence," Prentice Hall Int. Inc., USA, 1997.

[50] Matlab, The Mathworks, Inc. 2013.

\section{BIOGRAPHIES OF AUTHORS}

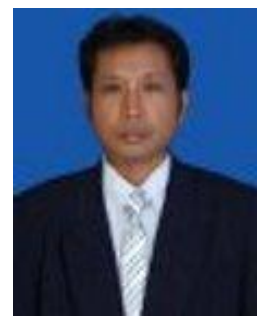

I Made Ginarsa was born in Darmasaba, Badung Bali Indonesia 1970. He received in B.Eng, M.Eng and Ph.D in elect. eng. UNUD (1997), UGM (2001) and ITS (2012). Since 1999 he was a lecturer at Elect. Eng., University of Mataram. In 2010 he was a member of EPS Lab., Kumamoto Univ. His research interests are dynamic and stability, nonlinear dynamic, voltage stability and artificial intelligent application in power systems. He was an active author, coauthor and invited reviewer on national and international publications. 

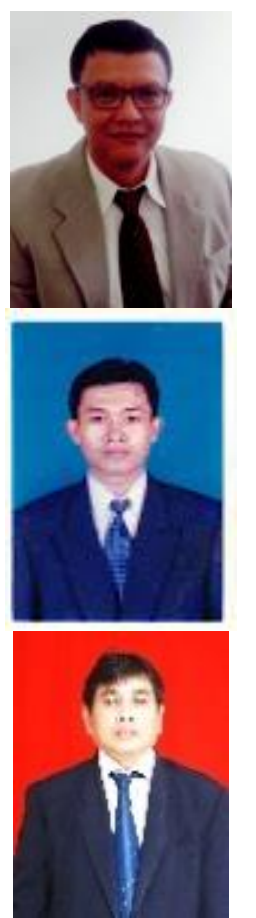

Agung B. Muljono, was born in Purwodadi Grobogan Indonesia, 1971. In 1998 he joined University of Mataram, Indonesia, as a lecturer. His research interests include transmission and distribution, dynamic and stability, artificial intelligent application, and energy planning and distributed generation in power systems. He received the B. Eng and M. Eng. in Electrical Eng. from Malang Institute of Technology (1996) and UGM (2000), respectively. He was an active author and co-author research papers and served as editorial board in Dielektrika Journal.

I Made Ari Nrartha, was born in Denpasar Bali Indonesia, 1973. He received in B.Eng and M.Eng in electrical eng. from ITS (1997) and UGM (2001). Since 1999 he was a lecturer at Electrical Eng., University of Mataram. His research interests are power system dynamic and stability, transmission and distribution, optimization, power quality and artificial intelligent application in power systems. He was an active author and co-author research papers in national and international journal, and served as editorial board in Dielektrika Journal.

S. Sultan, was born in Bulukumba South Sulawesi, Indonesia. He received the B. Eng. and M.Eng. degrees in Electrical Eng. from Hassanudin University (1995) and UGM (2005), respectively. In 1997 he was a lecturer in University of Mataram, Indonesia. His research interests include power system transmission and distribution, power system dynamic and stability in power systems. He was an active author and co-author research papers in national and international journal, and served as editor in chief of Dielektrika Journal 2010-2018. 